\title{
Deregulation, efficiency and competition in developing banking markets: Do reforms really work? A case study for Ghana
}

\author{
John K. Dadzie ${ }^{1}$ Alessandra Ferrari ${ }^{2}$
}

Published online: 22 March 2019

(c) The Author(s) 2019

\begin{abstract}
A key research question that remains largely unanswered especially in the African context is whether the macroeconomic environment and the level of financial development of a country determine the effectiveness of financial reforms. This has important policy implications. We choose Ghana as a case study and carry out an in-depth analysis of its comprehensive set of financial reforms, implemented in the 2000s, which we look at individually. We estimate a stochastic cost frontier to look at efficiency. This is then followed by two different models of competition on the loans market, the main target of the reforms. We find that only the removal of entry restrictions is significant at improving banks efficiency and that private and global foreign, but not regional banks, benefit from it. The results show, however, no improvements in competition, and reveal instead that macroeconomic and institutional weaknesses continue to exert a negative counterbalancing effect. Reforms need to be anchored on stronger macroeconomic fundamentals, institutional initiatives and generally stronger credit environments for their full potential to be revealed in the context of developing financial markets.
\end{abstract}

Keywords Bank efficiency · Financial reforms · Boone competition · Persistence of profits · African financial markets · Stochastic frontiers

\section{Introduction}

Banking in Africa has been undergoing gradual but notable changes since the turn of the 1990s, following the widespread introduction of financial reforms aimed at improving competition and efficiency. These reforms seem, however, to have had a limited impact [1]. Competition and efficiency in banking are key drivers of financial and economic development as they are expected to lower the cost of financial intermediation, improve access to banking services, facilitate innovation and contribute to the growth of the wider economy [2,3]. In the case of Africa, banking competition and efficiency assume greater significance due not only to the dominance of the sector in the overall financial system,

John K. Dadzie

john.dadzie@bog.gov.gh

$\triangle$ Alessandra Ferrari

a.ferrari@lboro.ac.uk

1 Research Department, Bank of Ghana, 1 Thorpe Road, Accra, Ghana

2 School of Business and Economics, Loughborough University, Loughborough LE11 3TU, UK but also to its relatively low development even by developing economies' standards [4]. Whether the effectiveness of crucial reforms is impaired by the macroeconomic environment and the level of financial development is therefore a very important policy question-yet one only scantily analysed.

We address this research question using as a case study the comprehensive set of financial reforms implemented in Ghana in the 2000s. We first analyse the changes in the cost efficiency of Ghana's commercial banks, the effectiveness of specific deregulation policies and the potential differences between ownership structures. We then estimate two separate complementary models to evaluate the changes in the competitive conditions of the sector. The reasons for our country choice are explained at the end of this section.

We contribute to the literature in several respects. First, while quite a lot of work exists on other developing countries, surprisingly little has focussed on African banking, especially at the country level. This could be due, among other reasons, to the difficulty in collecting good quality data. This important gap needs to be filled since the effect of regulatory policies varies crucially with the context and the level of financial development-with Africa scoring at the lower end of the scale. Country-level case studies in this 
respect are particularly suitable as they allow a more indepth analysis than aggregate cross-country comparisons. Secondly, unlike most of the literature, rather than looking at deregulation policies as a general category, we examine the (potentially different) impacts of specific deregulation policies on banking efficiency. To this aim we use the indexes produced by Barth et al. [5-8] and Abiad et al. [9]. Despite its informative power, this detailed approach is applied very seldom in the literature and it has never been followed in any studies on African banking. In our analysis of the determinants of efficiency, we also distinguish regional from global foreign banks, along with state-owned and private domestic ones. Thirdly, in our analysis of competition we choose to focus on the loans market rather than on the general banking industry. The loans market is the largest and most important segment of African banking and indeed the main target of the reforms. Fourthly, we estimate two separate models of competition: the persistence of profits (POP) model and the Boone indicator. ${ }^{1}$ Our choice is made for reasons of robustness (competition models can often lead to conflicting results) as well as completeness (the models allow for a different analysis of the dynamics of competition). Finally, unlike previous literature we specifically model different macroeconomic changes in the POP framework to address the question of whether reforms might be hindered by political and macroeconomic contexts [1]; and that macro-contexts more in general can interfere with the development of the positive effects of pro-competition policies [12].

There are several reasons behind our country choice, which we think make Ghana a very useful reference example to draw lessons for other African countries. Ghana is a lower-middle-income country and the second largest economy in West Africa. The first SSA country to gain independence in 1957, it played a key role in supporting the political independence of many SSA countries thereafter and, crucially, enjoyed the longest period of peace and stability; this facilitated the effective implementation of its financial reforms, offering an ideal context of analysis. The nature and scope of its banking regulations from the 1960s to the 1980s and their subsequent reforms reflected on those of many SSA countries. These reforms have been comprehensive and systematically pursued, helped also by the existence of a more reasonably autonomous central bank. Finally, we have access to a high-quality dataset, different from the commercially available ones that were shorter in time span, incomplete and at times also incorrect (for example, in banks classifications). Our data come from the audited financial statements and annual reports of banks, and it was made available to

\footnotetext{
${ }^{1}$ Most African banking studies use the Panzar-Rosse model which is easy to estimate but suffers from many serious limitations. See Bikker et al. [10] and Goddard and Wilson [11].
}

us by Ecobank Ghana Research, and cross-checked against similar information available from the Ghana Bankers Association. Data on regulatory indexes are obtained from the World Bank. Our final dataset is an unbalanced panel of 25 commercial banks for the period 2000-2014, thus covering both before and after the introduction of the reforms.

Our final results show that reforms had an overall positive effect on efficiency, but that this is specifically attributable almost exclusively to the relaxation of entry restrictions and to the technological superiority of foreign banks (as opposed to domestic or pan-African banks). Furthermore, improvements in efficiency cannot be ascribed to increased competitive pressures, as competitive conditions did not improve due to the counterbalancing negative effect of macroeconomic weaknesses.

The rest of the paper is organised as follows: the second section provides a brief overview of Ghana's banking sector and of its reforms. The third section summarises the main literature on the effects of deregulation on banking competition and efficiency. The fourth section discusses the methodology, models and data used. The fifth section discusses the empirical results, and the final section concludes.

\section{An overview of Ghana's banking sector and its reforms}

The evolution of Ghana's financial system mirrors the politico-economic ideologies of its governments over the years. The economic policy agenda following independence, for most part of the 1960s to the late 1980s, had a socialist orientation with a heavily regulated banking sector: entry restrictions were in place, with state banks dominating the sector, along with interest rate controls, credit ceilings, geographical and product restrictions, enormous reserve requirements and directed credit to support specific sectors of the economy. This meant an almost total absence of any competitive pressures, much like in other African countries [13]. The banking system was heavily concentrated with the top 4 banks holding $88 \%$ of deposits and $83 \%$ of total assets in $1981[14,15]$. The industry was not only uncompetitive, but also highly inefficient and saddled with stability challenges. Strict regulation meant that banks could not independently set interest rates to attract more deposits or grow their lending portfolios. The directed lending and credit ceilings also meant there was little commercial consideration in the selection and financing of projects. The long-term nature of some of the government projects financed, coupled with managerial incompetence, resulted in the sector being saddled with huge non-performing loans (NPLs) and operational losses which led to financial distress in the 1980s.

It is against this background that a process of financial deregulation started between the late 1980s and early 1990s, 
Table 1 Changes in banking market characteristics

\begin{tabular}{lllll}
\hline & 2000 & 2006 & 2009 & 2014 \\
\hline Banks & 16 & 21 & 25 & 24 \\
State & 5 & 5 & 5 & 4 \\
Private & 4 & 7 & 7 & 7 \\
Regional & 3 & 5 & 8 & 8 \\
Foreign & 4 & 4 & 5 & 5 \\
Fixed assets & 53.75 & 41.81 & 79.19 & 163.69 \\
Total assets & 263.0 & 246.348 & 348.261 & 621.03 \\
HHI & 0.148 & 0.090 & 0.068 & 0.058 \\
CR4 $(\%)$ & 68.5 & 49.4 & 43.7 & 34.1 \\
ROE & 0.52 & 0.23 & 0.10 & 0.34 \\
\hline
\end{tabular}

Means of inputs and outputs are in mil GHC, deflated. Regional banks are banks headquartered in other African countries. Newly licenced banks were included in the sample after 3 full years of operation

not only in Ghana but across many African countries, under the auspices of the IMF and the World Bank as part of broader structural adjustment programs.

In Ghana the first wave of financial reforms was the Financial Sector Adjustment Program (FINSAP), which started in 1988. These reforms led to a gradual liberalisation of interest rates and exchange rates; the abolition of directed lending; a clean-up of non-performing loans of banks; the recapitalisation or closure of insolvent banks; and the development of other components of the financial sector, including capital markets, insurance and other non-bank financial institutions. Their effect on banking competition and efficiency was, however, limited, with some of the lingering challenges identified by the literature in the fragmented banking sector, the existence of a few dominant banks, high concentration levels, limited market contestability and the high reserve requirements used to accommodate government deficit financing [13, 16, 17]. It was to address these challenges that the central bank initiated a second wave of reforms under its Financial Sector Strategic Plan (FINSSIP) in 2003-2006. These new deregulation policies included the introduction of universal banking in 2003 to remove product and geographical restrictions on banking activities; the adoption, in 2006, of an open licensing policy to enhance contestability and competition through the licensing of new banks; and the abolition of very large secondary reserve requirements in 2006 which compelled banks to hold 35\% of deposits in government securities, heavily constraining financial intermediation. The structural transformation of the banking sector following the new reforms appears quite substantial; a snapshot of this change is shown in Table 1 that looks at key market indicators for the years 2000, 2006, 2009 and 2014, representing the beginning and end of our sample period, the introduction of the reforms and their fuller implementation.
As we can see from the table, new banks enter the market, their number progressively increasing from 16 to 25 . Correspondingly the concentration levels of the industry decline as indicated by the Herfindahl-Hirschman Index (HHI) and the CR4 ratio; by 2014 the CR4 levels are very far from those of the 1980s that were higher than $80 \%$. Along with the overall decline in profit levels, this could suggest at first sight an increase in competition. The increase in the number of banks is also accompanied by a massive growth in branch network (proxied by the increase in fixed assets), the introduction of new products such as electronic banking, assets-backed lending and mortgage financing, and a general expansion of the sector (showed by the increase in total assets). The dominance of state banks is significantly curtailed as a more diversified ownership base arises that sees the presence of state, private domestic, regional (i.e. pan-African) and global foreign banks operating on a unified banking platform. While these figures would suggest a positive effect of the reform package on the market, the crucial issue is to empirically verify if it were successful at delivering its intended improvements in the efficiency and competitiveness of the sector. These are the two core questions we address in this paper, for their relevance per se and for the important policy implications that can be drawn for African countries similar to Ghana.

\section{Deregulation, banking competition and efficiency}

There is a very vast literature, both theoretical and empirical, on the impact of deregulation on competition and efficiency, with often conflicting results. A comprehensive review goes way beyond the scope of this paper, so we will focus on the main findings and especially on those relating to Africa. In very general terms, deregulation is expected to incentivise competition with improvements arising from the reduction in interest margins, the reduction in market power following the removal of entry and activity restrictions, and from the positive technological spillover effects of the entry of foreign banks with their superior technologies and risk management skills. The empirical evidence is, however, mixed. Some studies establish a positive impact of deregulation on competition in cross-country settings [13,18-21] and in singlecountry settings. ${ }^{2}$ In other studies this positive link is instead not found. ${ }^{3}$ The heterogeneity in results stretches from the effectiveness of deregulation (the size of the marginal gains

\footnotetext{
${ }^{2}$ See, for example, for the USA [22]. For the Philippines [23]. For Kenya [24]. Finally for Zambia [25].

3 This is the case, for instance, for US banking systems in Zardkoohi and Fraser [26]. And for Mexico in Maudos and Solís [27].
} 
from competition); the pace of these gains (which often depends on the level of financial and institutional development); the relevance of different macroeconomic and institutional factors; and the effect that competition has on the stability of the banking system overall. Very few studies look at the case of Africa, where a positive impact of deregulation on competition is found for South Africa, Algeria, Nigeria and Egypt through reduced concentration, privatisation and foreign bank entry (see footnote 2).

The impact of deregulation on banking efficiency is also not clear-cut. In most cases the effects are positive, but this is not always true. For example, Humphrey and Pulley (1997) find a negative impact for US banks; [28] their explanation is that the aggressive competition that followed deregulation of interest rates increased funding costs and adversely affected profit efficiency. Still for the USA Mester (1992) [29] also argues that inefficiency increased due to diseconomies of scope in the joint production of traditional and nontraditional banking activities. This could be due to the inexperience of managers in handling non-traditional banking activities and/or to the increase in agency costs if the joint production requires another layer of management. Negative effects were found also for Spain [30] and at least initially for China [31]. Among the reasons of the differential impacts are also the potentially opposite effects of deregulation policies, which could compensate one another [32], as we discuss in detail later. Since most studies look at deregulation as a whole body of reforms rather than focusing on its specific components, the different effects are not disentangled and the overall result is not fully explained. This is indeed one of the novel contributions of our work.

The inconsistency of results leaves the question of the effectiveness of deregulation policies an open issue, with the interaction of these policies and the stage of financial and economic development probably a crucial factor in determining the final outcome. This is the fundamental motivation of our study and of its focus on a seriously underresearched part of the world.

\section{Models, estimation techniques and data}

In the first part of our analysis, we estimate a stochastic cost frontier to evaluate the effectiveness of the reforms on banks cost efficiency, as well as its dynamics and determinants. This also provides us with an estimate of the marginal cost of loans, which is necessary for the second part of the analysis that focuses instead on the dynamics of competition. We adopt two separate, complementary approaches: the persistence of profits model (POP) and the Boone indicator. As mentioned in the introduction we do this for reasons of robustness (competition models can often lead to conflicting results) as well as completeness (the models allow for a different analysis of the dynamics of competition). The focus is on the loans market because it is the most important segment of the banking system in developing countries such as Ghana, and because the reforms were specifically targeted to address the challenges in this market. Our three models are explained below.

\section{The stochastic cost frontier model}

Given our research question we need a model that not only estimates efficiency and its changes over time, but also allows for its exogenous determinants. Our final specification, after a careful selection process, is Greene's true fixed effects model with a heteroskedastic, exponentially distributed inefficiency. The true fixed effects specification allows to disentangle the time varying inefficiency component from the individual, time invariant fixed effects. The explicit modelling of heteroskedasticity allows the introduction of exogenous influences on the inefficiency distribution. Two things are worth underlying here: first, unlike in OLS, the presence of heteroskedasticity produces biased and not just inefficient estimators. Secondly, inefficiency estimates would also be biased in the presence of heteroskedasticity. ${ }^{4}$ The model in its general specification reads as follows:

$\ln \mathrm{TC}_{i t}=\ln \mathrm{TC}\left(\ln x_{i t} ; \beta\right)+\varepsilon_{i t}$

$u_{i t} \sim E\left(\sigma_{u i t}\right)$ and $\sigma_{u i t}=\exp \left(z_{i t} ; w_{u}\right)$

Equation (1) models the stochastic cost frontier with fixed effects, with a dependent variable total cost (TC), a series of independent variables $x$ (output levels, input prices and other control variables) and a vector $\beta$ of parameters to be estimated. Equation (1) has a composite error term $\varepsilon_{i t}=v_{i t}+u_{i t}$ given by the sum of statistical noise $v_{i t} \sim N\left(0, \sigma_{v}^{2}\right)$ and inefficiency $u_{i t}$. Inefficiency is in turn modelled by Eq. (2) as an exponentially distributed variable with a heteroskedastic variance that depends on a set of covariates $\mathrm{z}_{\mathrm{it}}$. Equations (1) and (2) are estimated simultaneously by MLDV.

In line with most of the applied literature, we adopt a translog flexible functional form and follow the intermediation approach in the definition of the inputs and outputs of banks production process [34]. Linearity in inputs prices and

\footnotetext{
${ }^{4}$ A full discussion of these issues is beyond the scope of this paper. A good, brief recent review of these topics can be found, for example, in Kumbhakar et al. [33].
} 
symmetry conditions are applied prior to estimation leading to the following final model specification:

$$
\begin{aligned}
\ln \left(\mathrm{TC}_{i t}^{*}\right)= & \alpha_{i}+\beta_{0} E A_{i t}+\beta_{1} \ln w_{1 i t}^{*}+\beta_{11}\left(\ln w_{1 i t}^{*}\right)^{2} \\
& +\sum_{r} \gamma_{r} \ln y_{r i t}+\sum_{r} \sum_{s} \gamma_{r s} \ln y_{r} \ln y_{s} \\
& +\sum_{r} \psi_{r} \ln y_{r i t} \ln w_{i t}^{*}+\theta_{1} T+\theta_{11} T^{2} \\
& +\eta_{1} \ln w_{1 i t}^{*} T+\sum_{r} \zeta_{r} T \ln y_{r i t}+\tau_{1} \mathrm{DER}_{t} \\
& +\tau_{2} \mathrm{DER}_{t} T+\tau_{3} \mathrm{CRISIS}+\varepsilon_{i t}
\end{aligned}
$$

$$
\begin{aligned}
\sigma_{u i t}= & \exp \left(\delta_{0}+\delta_{1} \mathrm{ACTVR}_{t}+\delta_{2} \mathrm{ENTRYR}_{t}\right. \\
& +\delta_{3} \mathrm{CCR}_{t}+\delta_{4} \mathrm{DOM}_{i}+\delta_{5} \mathrm{REG}_{i} \\
& \left.+\delta_{6} \mathrm{FOR}_{i}+\delta_{7} \ln \mathrm{TA}_{i t}+\delta_{8} \mathrm{CRISIS}_{t}+e_{i t}\right)
\end{aligned}
$$

In Eq. (3) TC* is the total cost of bank $i$ at time $t$, given by the sum of interest and operating costs. Our three output variables are performing loans $\left(y_{1}\right.$, measured as the difference between total and non-performing loans), other earning assets ( $y_{2}$, given by investments in government securities and placements with other banks) and fee and commission income $\left(y_{3}\right)$, which is used as a proxy for off-balance sheet operations. Our input prices are the ratio of interest expense to loanable funds (the price of loanable funds, $w_{1}$ ), and the ratio of operating costs to total assets (the unit price of an aggregate input of labour, physical capital and other expenditure, $\left.w_{2}\right)$. The ratios $\mathrm{TC}^{*}=\mathrm{TC} / w_{2}$ and $w_{1} *=\left(w_{1} / w_{2}\right)$ are used to impose linear homogeneity in inputs prices. Technological change is modelled via a time trend $T$ that enters the equation quadratically. The trend variable is also interacted with inputs and outputs to model non-neutral and scale changing technology changes, respectively. The equity-toassets ratio (EA) is a measure of risk and at the same time an indication of the level of compliance with capital regulatory requirements. Finally, the impact of deregulation on the cost frontier itself (as opposed to inefficiency) is modelled via a deregulatory reform variable (DER) derived as the average of three individual deregulation policy variables modelled separately in the inefficiency function. DER is also interacted with the time trend variable to allow for the possible differential impact over time of deregulation over banks technology. For the determinants of inefficiency modelled by Eq. (4), we make the following choices. While deregulation as an aggregate is generally expected to improve efficiency, the individual effects of specific policies could be different and even conflicting, leading to opposite results. Ideally as in Eq. (4), we would like to model separately the deregulation
Table 2 Descriptive statistics for the key variables of the translog cost frontier

\begin{tabular}{lcrrrr}
\hline Variable & \multicolumn{2}{l}{ Mean } & & \multicolumn{2}{l}{ SD } \\
\cline { 2 - 5 } & 2000 & 2006 & 2009 & 2014 & $2000-2014$ \\
\hline TC & 31.2 & 25.2 & 44.9 & 64.5 & 31.47 \\
Loans & 99.6 & 110.2 & 157.1 & 272.6 & 141.52 \\
OEA & 109.7 & 94.3 & 111.9 & 185.0 & 132.21 \\
Fee income & 17.4 & 10.6 & 15.2 & 28.9 & 14.6 \\
Equity-to-assets ratio & 0.15 & 0.12 & 0.15 & 0.16 & 0.10 \\
Price of funds & 0.11 & 0.05 & 0.10 & 0.06 & 0.04 \\
Price of labour and & 0.09 & 0.07 & 0.07 & 0.06 & 0.03 \\
$\quad$ physical capital & & & & & \\
Cost to assets ratio & 0.16 & 0.12 & 0.11 & 0.10 & 0.04 \\
ACTVR & 0.33 & 0.47 & 0.67 & 0.67 & 0.11 \\
ENTRYR & 0.33 & 0.67 & 1.00 & 1.00 & 0.28 \\
CCR & 0.33 & 0.50 & 0.67 & 0.67 & 0.15 \\
DEREG & 0.33 & 0.54 & 0.76 & 0.76 & 0.18 \\
\hline
\end{tabular}

Means of inputs and outputs are in mil GHC, deflated. Indexes are proportions

policies via three indexes (ACTVR, ENTRYR and CCR). ${ }^{5}$ ACTVR measures the level of openness of banking activities. The removal of activities restrictions should in theory have a positive effect on the efficiency levels of banks [35], but results can vary depending on the development of the banking sector and on the ability of managers at dealing with activities other than traditional intermediation [32]. ENTRYR measures restrictions to entry, and we expect it to have a positive effect on efficiency via the improvements in competition and/or the technological spillover effects if new banks bring in better technologies. On the other hand, new entrants, especially if technologically superior, could cherry pick the best customers with serious detrimental effects for local banks [36]. CCR measures the extent of credit controls through reserve requirements, whose removal is expected to benefit efficiency. The problem we encountered with specification (4) is that the indexes are very highly correlated, with levels well above $90 \%$, making estimation very difficult and inference meaningless. We therefore use two alternative approaches. First we use the same aggregate variable DER used in (3), to capture the overall effect of deregulation on efficiency. Then, we use principal component analysis to try and disentangle the separate effects. More details are provided when discussing the results.

\footnotetext{
5 Derivation of ACTVR and ENTRYR is based on Barth et al. [5-8]. ACTVR measures activity restrictions and the mixing of banking and commerce. ENTRYR reflects the proportion of banking applications denied. CCR is based on the financial reform database by Abiad et al. [9]. All indexes are scaled to range from 0 to 1 for ease of interpretation and are all in increasing levels of liberalisation.
} 
Three dummy variables distinguish private domestic (DOM), African regional (REG) and foreign non-African (FOR) ownership structures, with state ownership used as the base category. Regional African banks have expanded quite substantially in recent years, and an open question in recent literature is to evaluate how they compare to global, non-African foreign banks given their closer cultural and geographical proximity to the host country. Bank size is controlled for by the (log of) total assets, and finally, CRISIS is a dummy variable set equal to 1 for the years following the global financial crisis. Some basic descriptive statistics are presented in Table 2.

In Table 2, the increasing level of costs and outputs confirms the increase in the size of the banking sector also seen in Table 1, while the lower input prices and the reduction in the ratio of total costs to total assets suggest an improvement in efficiency. The progressive implementation of the deregulatory reforms is also apparent in the increasing values of the regulatory indexes, while banks remain well capitalised. Equations (3) and (4) are estimated simultaneously via MLDV. ${ }^{6}$

\section{The POP model}

The idea behind the POP model is that of markets contestability: extra profits do not persist over time if a market is competitive. Vice versa, the less competitive is a market, the longer it will take for any extra profits to be eroded and reach a long run, perfectly competitive equilibrium. This idea can be captured by a partial adjustment model, whose essence can be written as follows [38]:

$\left(\ln \pi_{i t}-\ln \pi_{i t-1}\right)=a\left(\ln \pi *-\ln \pi_{i t-1}\right)+b R\left(\ln \pi *-\ln \pi_{i t-1}\right)+\varepsilon_{i t}$

In Eq. (5) $\pi$ is the ratio of price to marginal cost, a measure of profitability. The equation models the adjustment of profitability towards its perfectly competitive long-run equilibrium $\pi^{*}$ where price equals marginal cost and thus the ratio is equal to 1 (and its natural $\log$ is 0 ). The parameter $a$ is the speed of adjustment of this process, with $0<a<1$ and larger values indicating a faster adjustment towards equilibrium. $\mathrm{R}$ is a dummy variable modelling the introduction of policy changes that could lead to a faster $(b>0)$ or slower $(b<0)$ adjustment.Rearranging Eq. (5), we get:

$\ln \pi_{i t}=\alpha \ln \pi_{i t-1}+\gamma R \ln \pi_{i t-1}+\varepsilon_{i t}$

In Eq. (6) we can see that $\alpha=1-a$ is the persistence parameter, and that $\gamma=-b$. We adopt this set-up in our final specification.

Unlike previous work, instead of simply aggregating all other exogenous macroeconomic factors (for instance, into time effects or GDP growth) we specifically introduce them into the equation. This allows us to clearly identify which, if any, might play a role in determining the level of profitability

\footnotetext{
${ }^{6}$ We run the estimations using the code provided by Belotti et al [37].
}

of the industry at each point in time, besides the interplay of competitive forces. We are particularly interested in this point because there are suggestions in the literature that macroeconomic and/or institutional characteristics might be a hurdle to the full working of reform packages in the developing world. Our final specification reads as follows:

$$
\begin{aligned}
\ln \mathrm{LOC}_{i t}= & \alpha \ln \mathrm{LOC}_{i, t-1}+\gamma R * \ln \mathrm{LOC}_{i, t-1} \\
& +\kappa_{1} \mathrm{CRISIS}_{t}+\kappa_{2} \mathrm{GDP}_{t}+\kappa_{3} \mathrm{MPR}_{t} \\
& +\kappa_{4} \mathrm{TBR}_{t}+\kappa_{5} \mathrm{FIS}_{t}+\varepsilon_{i t}
\end{aligned}
$$

In Eq. (7) the dependent variable is the (log of the) loan overcharge of bank $i$ at time $t\left(\mathrm{LOC}_{i t}\right)$. This is a measure of profitability on the market of loans (the focus of our competition analysis), and it is defined as the ratio of the price of loans to their marginal cost. ${ }^{7}$ The policy dummy variable $R$ takes a value of 1 for the years following the full implementation of the deregulation reforms (2007 onwards). ${ }^{8} \mathrm{~A}$ non-significant $\gamma$ will indicate no change in the competitive conditions following the reforms. A positive and significant $\gamma$ will reflect a reduction in competition and vice versa. The possible impact of macroeconomic policies is captured by the real monetary policy rate (MPR), the real treasury bill rate (TBR) and the fiscal balance-to-GDP ratio (FIS). The real growth rate of GDP aggregates all other remaining factors, and the dummy variable CRISIS captures the years following the financial crisis. Given its dynamic panel structure the model is estimated using the Arellano-Bond GMM two-step estimator, backed up for robustness checks by the Arellano-Bover. Our primary focus is the result on the persistence parameters $\alpha$ and $\gamma$. The macroeconomic and industry-specific variables provide further insight into the determination of the loan overcharge and hence other determinants of competition.

\section{The Boone indicator of competition}

To increase the robustness of the results and to track more in detail the dynamics of competition over time, we also estimate the Boone indicator. The framework of analysis of the Boone model is a Cournot-Nash static oligopoly model of firms with different marginal costs. The key idea is to measure the competitive environment by examining the extent to which relatively more efficient firms are able to gain market share or increase profits at the expense of less efficient firms

\footnotetext{
7 The price of loans is in turn calculated as the ratio of interest income to total loans, while the marginal cost is obtained from the estimation of Eq. (3).

${ }^{8}$ This is in recognition of the fact that the introduction of the full package of reforms was completed in 2006. To allow for possible lagged effects of policy reforms, we also tried different cut-off points for the dummy variable but the results of these alternative specifications were not significantly better.
} 
Table 3 Key estimation results of the cost frontier, Eq. (3)

\begin{tabular}{|c|c|c|c|c|c|c|}
\hline Variable & Parameter & & Coefficient & & SD & $P$ value \\
\hline$T$ & $\theta_{1}$ & & 0.010 & & 0.003 & 0.677 \\
\hline$T^{2}$ & $\theta_{11}$ & & 0.000 & & 0.005 & 0.807 \\
\hline$T \ln w^{*}$ & $\eta_{1}$ & & 0.004 & & 0.003 & 0.256 \\
\hline$T \ln y_{1}$ & $\zeta_{1}$ & & $-0.011^{b}$ & & 0.005 & 0.028 \\
\hline$T \ln y_{2}$ & $\zeta_{2}$ & & $-0.012^{\mathrm{a}}$ & & 0.004 & 0.002 \\
\hline$T \ln y_{3}$ & $\zeta_{3}$ & & $0.021^{\mathrm{a}}$ & & 0.005 & 0.000 \\
\hline DER & $\tau_{1}$ & & 0.210 & & 0.378 & 0.593 \\
\hline TDER & $\tau_{2}$ & & 0.038 & & 0.045 & 0.406 \\
\hline Crisis & $\tau_{3}$ & & $0.097^{\mathrm{a}}$ & & 0.034 & 0.004 \\
\hline Equity/assets & $\beta_{0}$ & & $-0.642^{\mathrm{a}}$ & & 0.117 & 0.000 \\
\hline Elasticities & State & Domestic & & Regional & Foreign & All \\
\hline$y_{1}$ & $0.523^{\mathrm{a}}$ & $0.533^{\mathrm{a}}$ & & $0.443^{\mathrm{a}}$ & $0.441^{\mathrm{a}}$ & $0.487^{\mathrm{a}}$ \\
\hline$y_{2}$ & $0.290^{\mathrm{a}}$ & $0.299^{\mathrm{a}}$ & & $0.356^{\mathrm{a}}$ & $0.407^{\mathrm{a}}$ & $0.335^{\mathrm{a}}$ \\
\hline$y_{3}$ & $0.093^{b}$ & $0.063^{b}$ & & $0.098^{\mathrm{b}}$ & $0.048^{\mathrm{b}}$ & $0.076^{\mathrm{b}}$ \\
\hline Returns to scale & 1.10 & 1.12 & & 1.11 & 1.12 & 1.11 \\
\hline$w_{1}$ & $0.351^{\mathrm{a}}$ & $0.414^{\mathrm{a}}$ & & $0.329^{\mathrm{a}}$ & $0.303^{\mathrm{a}}$ & $0.354^{\mathrm{a}}$ \\
\hline$w_{2}$ & $0.649^{\mathrm{a}}$ & $0.586^{\mathrm{a}}$ & & $0.671^{\mathrm{a}}$ & $0.697^{\mathrm{a}}$ & $0.646^{\mathrm{a}}$ \\
\hline
\end{tabular}

Superscripts a, b and c indicate significance at $1 \%, 5 \%$ or $10 \%$ levels, respectively. $y_{1}, y_{2}$ and $y_{3}$ are respectively loans, OEA and fee income. $w_{1}$ and $w_{2}$ are the price of funds and the price of labour and physical capital

(the so-called reallocation process) [39, 40]. The higher the intensity of competition, the greater the reallocation of market shares from inefficient to more efficient firms, and vice versa. The model accordingly examines the relationship between performance and efficiency to infer competitiveness. In the applications of this model, the former is generally measured as profitability or market share, and the latter as marginal costs. ${ }^{9}$ We follow Van Leuvensteijn et al. [41] and specify our estimable Boone model as follows:

$\ln \mathrm{MS}_{i t}=\alpha+\sum_{t=1}^{T} \beta_{t} D_{t} \ln \mathrm{MC}_{i t}+\varepsilon_{i t}$

In Eq. (8), $\mathrm{MS}_{i t}$ is the market share of loans of bank $i$ in year $t$ and $\mathrm{MC}_{i t}$ is the marginal cost of loans [as estimated from Eq. (3)]. $D_{\mathrm{t}}$ is a vector of $T$ year-specific dummy variables to allow the Boone indicator to vary over time; competition and its yearly evolution are measured by the resulting vector of parameters $\beta_{t}$. A priori, $\beta$ is expected to be negative due to the inverse relationship between marginal cost and loan market share. There is no threshold of reference for the Boone indicator, but the higher the absolute value of $\beta$, the greater the intensity of competition.

Due to the possible endogeneity of MC, Eq. (8) is estimated using a GMM-IV estimator, using lagged values of

\footnotetext{
9 See, for instance, Van Leuvensteijn et al. [41], Schaeck and Čihák
} [42] and Clerides et al. [43].
MC as instruments. A simpler 2SLS estimator is also used for robustness comparisons, as is a simple fixed effects estimator. As we will see, despite the endogeneity issue, the resulting pattern of the coefficients is the same in all 3 specifications, hence further supporting our final conclusions.

Our data are an unbalanced panel dataset of 25 banks observed over 15 years (2000-2014) for a total of 321 observations. Bank-level data were compiled from audited financial statements of banks. Macroeconomic data are obtained from the Bank of Ghana annual reports and the IMF's World Economic Outlook database. All the bank-level data were adjusted to real values using the GDP deflator with 2006 as the base year.

Table 4 Estimation results of the inefficiency model, Eq. (4)

\begin{tabular}{llcll}
\hline & Parameter & Coefficient & SD & $P$ value \\
\hline ACTVR (PCA1) & $\delta_{1}$ & -21.61 & 14.67 & 0.138 \\
ENTRYR (PCA2) & $\delta_{2}$ & $-6.42^{\mathrm{a}}$ & 1.600 & 0.000 \\
CCRR (PCA3) & $\delta_{3}$ & 8.11 & 8.50 & 0.340 \\
DER & $\delta_{0}$ & $-5.70^{\mathrm{b}}$ & 2.39 & 0.017 \\
DOM & $\delta_{4}$ & $-0.99^{\mathrm{c}}$ & 0.57 & 0.085 \\
REG & $\delta_{5}$ & -0.34 & 0.54 & 0.524 \\
FOR & $\delta_{6}$ & $-1.01^{\mathrm{c}}$ & 0.61 & 0.096 \\
ln TA & $\delta_{7}$ & -0.14 & 0.34 & 0.686 \\
CRISIS & $\delta_{8}$ & 0.95 & 0.68 & 0.16 \\
\hline
\end{tabular}

Superscripts a, b and c indicate significance at $1 \%, 5 \%$ or $10 \%$ levels, respectively 


\section{Estimation results and analysis}

\section{Stochastic cost frontier and efficiency levels}

Tables 3 and 4 report the key results of the estimation of the SFA model of Eqs. (3) and (4). The cost function parameters have the expected signs and meet all regularity requirements.

Inputs and outputs elasticities are positive and significant as expected. Loans and other earning assets are the most relevant in affecting banks costs, and both enjoy technological progress over time.

Fee income is the least relevant, as reflected by its low significance, and becomes instead increasingly costly. This result is understandable in the context of less developed financial markets where banks still focus largely on traditional intermediation and the acquisition of government bonds; very little space is given to off-balance sheet items, for which managers have much less expertise (see also Table 2). Neutral technological change is instead not significant. All bank types enjoy mild but significant increasing returns to scale,${ }^{10}$ consistent with a relatively small sized market. The introduction of deregulation as such does not have any significant effect on the technology of production, or more precisely none that can be disentangled from the non-neutral technical change discussed above. It does instead have a significant effect on inefficiency as we discuss hereinafter.

Turning to Eq. (4), inefficiency is modelled as an exponential distribution with heteroskedastic variance. Variables that affect the variance also affect the mean of the distribution, i.e. the expected value of inefficiency. The estimation as specified in (4) presented some issues due to the high level of collinearity between the regulatory indexes. We therefore adopted two alternative specifications. In the first one, we replaced the three separate indexes with the average DER variable used also in the frontier. This allows us to see whether changes in overall deregulatory intensity had a positive or negative effect on efficiency (i.e. decreased or increased inefficiency). In the second approach, we used principal component analysis to remove the correlation between indexes. We constructed three vectors (labelled PCA1, PCA2 and PCA3) which capture, respectively, the variation in activity restrictions (ACTVR), entry restrictions (ENTRYR) and credit controls (CCR). ${ }^{11}$

Our results indicate that increasing levels of deregulation overall have a positive effect on efficiency (i.e. they

\footnotetext{
10 The hypothesis of constant returns to scale at the sample mean is rejected at the $1 \%$ level.

11 The three eigenvectors are $e 1(1 ;-0.59 ; 0.42), e 2(0.37 ; 1 ; 0.52)$ and $e 3(-0.60 ;-0.30 ; 1)$, and they are used in the construction of the 3 PCA vectors using the regulatory indexes in the order ACTR, ENTRYR and CCR.
}

significantly reduce inefficiency). More specifically the removal of entry restrictions is the most effective deregulatory tool, whereas the removal of activity restrictions is significant only at the $13.8 \%$ and the removal of credit controls is not significant at all. We interpret the low significance of ACTVR in light of the somewhat limited scope of the implementation of this policy: while universal banking in principle broadened the definition of banking to include leasing, mortgage financing and insurance business, these non-core banking activities did not really take off much in Ghana (similarly to other African countries). As we were saying above, banks seem to focus on their traditional banking business, with little diversification.

The relaxation of entry restrictions (ENTRYR) instead contributes significantly to reducing cost inefficiency. This improvement could be a result of increased competitive pressures on the market, and/or of positive technological spillovers if the new banks have better technologies than the incumbents. Given the results we discuss below on foreign banks, and the ones we obtain later on competition, we support the second explanation; we elaborate on this point more clearly in the conclusions to the work. Finally, the index more closely and positively related to CCR (the removal of credit restrictions through the reduction of reserve requirements) has a positive coefficient but is highly non-significant. This lack of significance might reflect the fact that banks were not yet "good enough" at efficiently managing the extra liquidity. Strong credit growth is usually accompanied by high non-performing loans and higher loan loss provisions, especially where the credit environment is not supportive of such loan growth. The significant growth in loans following the relaxation of credit constraints and the high resulting NPLs could have counteracted any potential efficiency-improving effects. However, it could also be a statistical effect resulting from the low variability of the variable itself, in turn affected by the two negative weights given to the other components which have a counterbalancing effect. Indeed, these index specific results have to be taken with some caution as the PCA vectors by construction do not perfectly capture the variation in the original indexes with the possible exception of PCA2.

Turning to the effect of ownership, global foreign and private domestic banks are significantly more efficient than state banks. This result is in line with that vast part of the literature which supports the superiority of private ownership, and with the so-called "global advantage" theory of foreign banking that finds supportive evidence especially in developing economies. The advantage does not, however, significantly extend to African regional banks. This is in line with very recent literature [44] that also finds that the cultural and regional proximity of regional African banks do not translate in cost advantages and better general performance. This 
Table 5 Results of the estimation of the POP model, Eq (7) using Arellano-Bond and Arellano-Bover for robustness (SD in parenthesis)

\begin{tabular}{|c|c|c|c|c|c|}
\hline & \multirow[t]{2}{*}{ Parameter } & \multicolumn{2}{|c|}{ Arellano-Bond } & \multicolumn{2}{|l|}{ Arellano-Bover } \\
\hline & & Estimate & $P$ value & Estimate & $P$ value \\
\hline $\operatorname{lnLOC}_{t-1}$ & $\alpha$ & $\begin{array}{l}0.249 \\
(0.127)\end{array}$ & 0.049 & $\begin{array}{l}0.376 \\
(0.104)\end{array}$ & 0.000 \\
\hline$R^{*} \operatorname{lnLOC}{ }_{t-1}$ & $\gamma$ & $\begin{array}{l}-0.025 \\
(0.095)\end{array}$ & 0.796 & $\begin{array}{l}-0.049 \\
(0.109)\end{array}$ & 0.653 \\
\hline CRISIS & $\kappa_{l}$ & $\begin{array}{l}0.181 \\
(0.051)\end{array}$ & 0.000 & $\begin{array}{l}0.162 \\
(0.051)\end{array}$ & 0.001 \\
\hline GDP & $\kappa_{2}$ & $\begin{array}{l}-0.010 \\
(0.005)\end{array}$ & 0.038 & $\begin{array}{l}-0.017 \\
(0.0051)\end{array}$ & 0.001 \\
\hline MPR & $\kappa_{3}$ & $\begin{array}{l}2.780 \\
(0.677)\end{array}$ & 0.000 & $\begin{array}{l}3.703 \\
(1.036)\end{array}$ & 0.000 \\
\hline TBR & $\kappa_{4}$ & $\begin{array}{l}-1.129 \\
(0.502)\end{array}$ & 0.024 & $\begin{array}{l}-1.180 \\
(0.524)\end{array}$ & 0.024 \\
\hline FIS & $\kappa_{5}$ & $\begin{array}{l}-0.007 \\
(0.009)\end{array}$ & 0.430 & $\begin{array}{l}-0.008 \\
(0.079)\end{array}$ & 0.283 \\
\hline \# instruments & 102 & & & 117 & \\
\hline \multicolumn{6}{|l|}{ AR tests } \\
\hline ord 1 & $-2.5455(P$ value 0.0109$)$ & & & $-2.9962(P$ value 0.0027$)$ & \\
\hline ord 2 & $-0.5147(P$ value 0.6068$)$ & & & $-0.6914(P$ value 0.4893$)$ & \\
\hline $\begin{array}{l}\text { Sargan test for } \\
\text { overidentifying } \\
\text { restrictions }\end{array}$ & $15.490(P$ value $=1.000)$ & & & $15.485(P$ value $=1.000)$ & \\
\hline
\end{tabular}

disadvantage has been attributed to the longer experience of foreign global competitors, their better access to funding and stronger support from headquarters in IT and risk management. Finally, total assets are not significant, whereas the financial crisis as expected has an adverse impact on efficiency. The general trend of efficiency over time is positive, growing quite steadily from an average of $88 \%$ before the reforms to one of $93 \%$ afterwards with levels as high as $95.4 \%$ just before the financial crisis.

So overall this part of the analysis shows that deregulation brought some beneficial effects in terms of efficiency improvements but that not all deregulatory policies contributed equally, if at all, to it. It also shows important differences between ownership types with private and global foreign ownerships prevailing upon public and regional ones.

Using the estimated stochastic cost frontier results, we next calculate the observation-specific marginal cost of loans, which is used to derive both the LOC variable of the POP model and the explanatory variable for the Boone model.

\section{Results of the POP model}

The specification of the POP model is reported in Eq. (7). The presence of a lagged dependent variable (LDV) in the equation prevents us from using a fixed effects estimator since the differencing transformation used to eliminate the fixed effects creates correlation between the differenced LDV and the differenced error (the so-called Nickell bias).
We therefore use dynamic panel estimators. The Arellano-Bond GMM difference estimator, which uses lagged levels of the differenced LDV as instruments, is estimated first. For robustness we also estimate the Arellano-Bover GMM system estimator, which augments the Arellano-Bond by adding a level equation instrumented using lagged differences. Both estimators are implemented in their more asymptotically efficient two-step version, with Windmeijercorrected standard errors to adjust for the resulting downward bias. The models produce consistent results, and both pass the tests for second-order autocorrelation and for overidentifying restrictions, necessary for consistency. The results are reported in Table 5.

The key results from Table 5 are the estimated values of $\alpha$ and $\gamma$ of Eq. (7). As expected, we find that $\alpha$ is positive and significant, with a value of 0.249 . However, $\gamma$ is highly not significant, indicating that the reforms had no discernible effect on the competitiveness of the industry. ${ }^{12} \mathrm{~A}$ similar non-significant effect was found by Poshakwale and Qian [45] who studied the impact of the reforms introduced in Egypt in the early 2000s. Their persistence coefficient though was much higher (0.810) as was the one found by Mwega (see footnote 2 ) for Kenya (0.451); if a comparison could be made, this would suggest stronger competitive conditions in Ghana than in other SSA countries.

\footnotetext{
$\overline{12}$ This result was robust to different cut-off points for the R dummy variable.
} 
Table 6 Results of the estimation of the Boone model of Eq. (8), 2000-2014, GMM-IV

\begin{tabular}{llllllll}
\hline Year & Coefficient & SD & $P$ value & Year & Coefficient & SD & $P$ value \\
\hline 2002 & -2.895 & 0.436 & 0.000 & 2009 & -2.808 & 0.401 & 0.000 \\
2003 & -2.873 & 0.428 & 0.000 & 2010 & -2.565 & 0.367 & 0.000 \\
2004 & -2.686 & 0.397 & 0.000 & 2011 & -2.403 & 0.336 & 0.000 \\
2005 & -2.649 & 0.388 & 0.000 & 2012 & -2.348 & 0.324 & 0.000 \\
2006 & -2.447 & 0.353 & 0.000 & 2013 & -2.395 & 0.331 & 0.000 \\
2007 & -2.436 & 0.359 & 0.000 & 2014 & -2.395 & 0.331 & 0.000 \\
2008 & -2.499 & 0.361 & 0.000 & Hausman & $\chi^{2}(13)=553.85$ & & \\
& & & & & $P$ value 0.000 & &
\end{tabular}

2000 and 2001 were omitted by GMM for collinearity reasons. The Hausman test for endogeneity compares the GMM estimator with the fixed effects one
Fig. 1 The annual Boone competition measures, 2000-2014

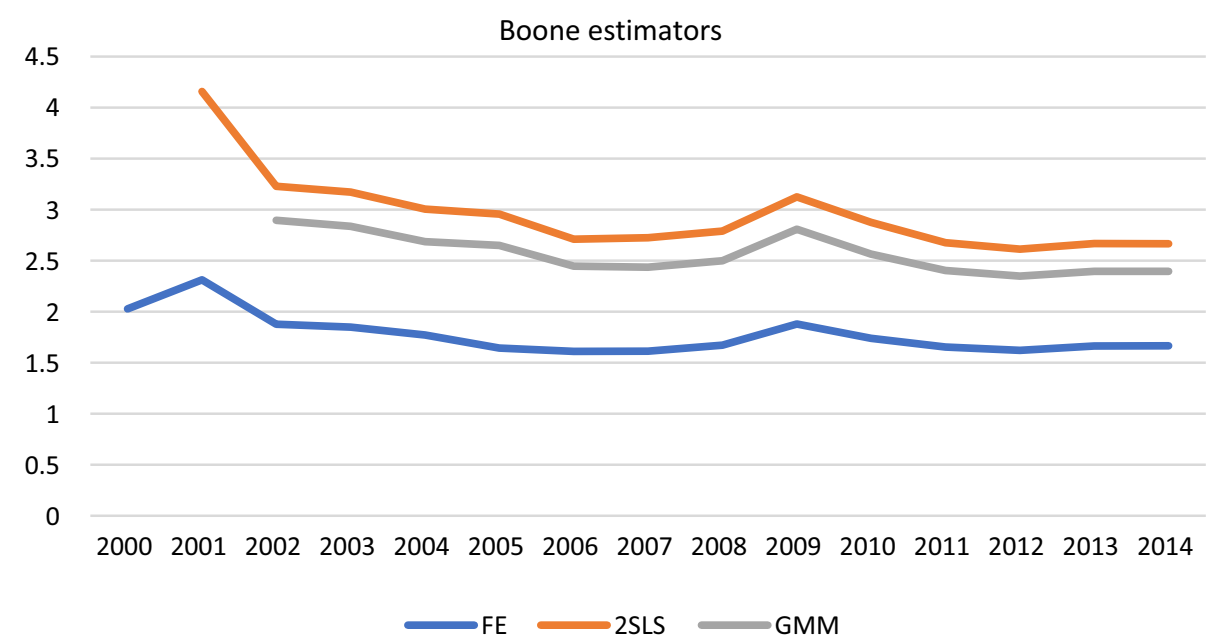

To fully understand this result, we look at the remaining coefficients. A significant positive effect on the loan overcharge is exerted by changes in the real monetary policy rate $(\mathrm{MPR})^{13}$ and by the financial crisis. This is in line with our expectations. Periodic changes in the MPR, announced by the central bank, feed directly into loan pricing and deposit rates adjustments by banks, and the MPR oscillated quite a lot throughout the time period, increasing quite steadily since 2009. Reductions in the loan overcharge are instead produced by increases in the treasury bill rate (TBR). We interpret this result in the particular context of underdeveloped financial markets such as Ghana's. Increases in TBR increase the investment by banks in treasury bills, and this reduces loanable funds available for private sector lending. If the supply of loans to the private sector is severely curtailed, in underdeveloped financial markets banks might

\footnotetext{
13 The large size of this coefficient reflects the fact that while MPR is a real rate, the LOC variable is essentially nominal since the same deflation factor has been applied to both numerator and denominator in its construction.
}

selectively restrict lending to creditworthy large corporates and reputable medium-sized companies all of whom call for lower loan overcharge rates. The reduction in loan overcharge is also feasible if the interest income from investment in treasury bills more than compensates for it. GDP growth reduces as expected the loan overcharge, whereas changes in the fiscal balance have no significant effect.

In summary, although deregulation was expected to improve the competitiveness of the loans market, this effect was impaired by the overcompensating playing of macroeconomic developments. To double-check the robustness of these results, and to look more in detail at the dynamics of competition on the loans market, we next estimate as an alternative model the Boone indicator.

\section{Results of the Boone indicator model}

The Boone model of Eq. (8) expects a negative relationship between marginal costs and market share via the so-called "reallocation process" that benefits efficient firms; an increase in the absolute value of this negative 
coefficient indicates an increase in the competitive pressures of the market. We first estimate the model using a simple fixed effects model. The possible endogeneity of MC is confirmed by a Hausman test carried out between the fixed effects specification and the alternative GMMIV specification, where lagged values of MC are used as instruments. A simpler 2SLS estimator is also used for a final robustness comparison. The results of the GMM estimator are presented in Table 6; their pattern along with that of the fixed effects and of the 2SLS estimators is plotted in Fig. 1.

The pattern is depicted in Fig. 1, which shows the consistency in the results across the three different estimation techniques and thus the robustness of our final inference. ${ }^{14}$ In the figure for ease of interpretation, we have turned the negative coefficient values into positive ones so that increases and decreases in the pattern correspond to increases and decreases in competition. The figure shows that competitive conditions are stronger at the beginning of the data series and slowly worsen over time, apart from a short-lived mild improvement in 2009. Once again we find that the reform package does not seem to have had the desired competition-inducing effects. It is possible that banks found government securities more profitable, consistently with what we saw in the POP model; or that they started resenting from the higher loan defaults that resulted from the excessive growth in loan portfolio in 2007-2008 in response to the scrapping of secondary reserves and higher interest rates. All in all, the intensity with which efficient banks sought to win market share in loans from less efficient ones dwindled, resulting in the low beta coefficients.

\section{Conclusions}

This paper examines the impact of deregulation reforms on the efficiency and competitiveness of banks in Ghana using a panel dataset of 25 banks for the period 2000-2014 which captures the pre- and post-reform periods. A stochastic cost frontier model with heteroskedastic inefficiency is used to analyse the levels and determinants of efficiency, along with principal component analysis to evaluate the effects of different policies. The resulting estimates also provide us with the marginal cost of loans which feeds into the modelling of competition. The competitiveness of the market for loans is evaluated by estimating two complementary models: the POP model and the Boone indicator. The empirical

\footnotetext{
${ }^{14}$ Please note that what matters in the Boone estimator is not the size of the coefficients, for which there is no reference value apart from the negative sign, but their pattern over time.
}

results are very interesting and shed a lot of light on the workings of banking markets in less developed financial systems. First of all we find that efficiency improved over time and in particular following the introduction of deregulation. Crucially, however, the only policy that seems to really help improve banks efficiency is the relaxation of entry restrictions that encouraged the full development of the superior technology of private banks and in particular of global foreign banks, as opposed to African regional ones. The removal of activities restrictions and the reduction of reserve requirements, with the extra liquidity that they provide, do not instead help as much. This suggests that banks in Ghana (and possibly in Africa in general) do not really exploit the potential benefits of product differentiation made possible by universal banking. Most importantly, improvements in efficiency cannot be the result of increased competitive pressures: the results of both the POP and the Boone models suggest that competitive conditions do not improve after the implementation of the reforms. As suggested by other literature, this appears to be due to the counterbalancing negative effect of macroeconomic weaknesses. So while cost savings can be enjoyed and efficiency improved, the full benefits of product diversification and increased competition are not exploited. The policy implications are that the macroeconomic and institutional contexts for African countries are still crucial for them to fully benefit from financial deregulation. Reforms need to be anchored on stronger macroeconomic fundamentals, institutional initiatives and generally stronger credit environments for their full potential to be revealed.

Acknowledgements We would like to thank the Commonwealth Scholarship Commission for the funding provided under their CSFP scheme to support the completion of this project. We would also like to thank Ecobank Ghana Research for having provided access to the dataset.

Open Access This article is distributed under the terms of the Creative Commons Attribution 4.0 International License (http://creat ivecommons.org/licenses/by/4.0/), which permits unrestricted use, distribution, and reproduction in any medium, provided you give appropriate credit to the original author(s) and the source, provide a link to the Creative Commons license, and indicate if changes were made.

\section{References}

1. Beck, T., and R. Cull. 2013. Banking in Africa. World Bank Policy Research Working Paper no. 6684.

2. Allen, F., and D. Gale. 2000. Comparing financial systems. Cambridge, MA: MIT Press.

3. Claessens, S. 2009. Competition in the financial sector: Overview of competition policies. Washington: IMF. WP 09/45.

4. Allen, F., I. Otchere, and L.W. Senbet. 2011. African financial systems: A review. Review of Development Finance 1(2): 79-113. 
5. Barth, J.R., G. Caprio, and R. Levine. 2001. The regulation and supervision of banks around the world: A new database. Washington: World Bank.

6. Barth, J.R., G. Caprio, and R. Levine. 2003. The regulation and supervision of banks around the world: A new database. Washington: World Bank.

7. Barth, J.R., G. Caprio, and R. Levine. 2007. The regulation and supervision of banks around the world: A new database. Washington: World Bank.

8. Barth, J.R., G. Caprio, and R. Levine. 2012. The regulation and supervision of banks around the world: A new database. Washington: World Bank.

9. Abiad, A., E. Detragiache, and T. Tressel. 2010. A new database of financial reforms. IMF Staff Papers 57(2): 281-302.

10. Bikker, J.A., S. Shaffer, and L. Spierdijk. 2012. Assessing competition with the Panzar-Rosse model: The role of scale, costs, and equilibrium. Review of Economics and Statistics 94(4): $1025-1044$.

11. Goddard, J., and J.O.S. Wilson. 2009. Competition in banking: A disequilibrium approach. Journal of Banking \& Finance 33(12): 2282-2292.

12. Chauvet, L., and L. Jacolin. 2017. Financial inclusion, bank concentration, and firm performance. World Development 97 : $1-13$.

13. Kasekende, L., K. Mlambo, V. Murinde, and T. Zhao. 2009. Restructuring for competitiveness: The financial services sector in Africa's four largest economies. World Economic Reform: Africa Competitiveness Report 209: 49-81.

14. Antwi-Asare, T.O., and E.K.Y. Addison. 2000. Financial sector reforms and bank performance in Ghana. London: Overseas Development Institute.

15. Ayyagari, M., A. Demirguc-Kunt, and V. Maksimovic. 2013. Financing in developing countries. Handbook of the Economics of Finance 2: 683-757.

16. Biekpe, N. 2011. The competitiveness of commercial banks in Ghana. African Development Review 23(1): 75-87.

17. Buchs, T.D., and J. Mathisen. 2005. Competition and efficiency in banking: behavioral evidence from Ghana. Washington, DC: African Department, International Monetary Fund.

18. Claessens, S., A. Demirgüç-Kunt, and H. Huizinga. 2001. How does foreign entry affect domestic banking markets? Journal of Banking \& Finance 25(5): 891-911.

19. Claessens, S., and L. Laeven. 2004. What drives bank competition? Some international evidence. Journal of Money, Credit and Banking 36(3): 563-583.

20. Delis, M.D. 2012. Bank competition, financial reform, and institutions: The importance of being developed. Journal of Development Economics 97(2): 450-465.

21. Brissimis, S., M. Iosifidi, and M.D. Delis. 2014. Bank market power and monetary policy transmission. International Journal of Central Banking 10(4): 173-214.

22. Cetorelli, N. 2002. Entry and competition in highly concentrated banking markets. Economic Perspectives 26(4): 18-27.

23. Pasadilla, G., and M. Milo. 2005. Effect of liberalization on banking competition. Philippine Institute for Development Studies, Discussion papers series DP 2005-03.

24. Mwega, F. 2011. The competitiveness and efficiency of the financial services sector in Africa: A case study of Kenya. African Development Review 23(1): 44-59.

25. Simpasa, A.M. 2013. Increased foreign bank presence, privatisation and competition in the Zambian banking sector. Managerial Finance 39(8): 787-808.
26. Zardkoohi, A., and D.R. Fraser. 1998. Geographical deregulation and competition in US banking markets. Financial Review 33(2): 85-98.

27. Maudos, J., and L. Solís. 2011. Deregulation, liberalization and consolidation of the Mexican banking system: Effects on competition. Journal of International Money and Finance 30(2): 337-353.

28. Humphrey, D.B., and L.B. Pulley. 1997. Banks' responses to deregulation: Profits, technology, and efficiency. Journal of Money, Credit and Banking 29(1): 73-93.

29. Mester, L.J. 1992. Traditional and non-traditional banking: An information-theoretic approach. Journal of Banking \& Finance 16: 545-566.

30. Kumbhakar, S.C., A. Lozano-Vivas, C.A.K. Lovell, and I. Hasan. 2001. The effects of deregulation on the performance of financial institutions: The case of Spanish savings banks. Journal of Money, Credit and Banking 33(1): 101-120.

31. Dong, Y. 2010. Cost efficiency in the Chinese banking sector: A comparison of parametric and non-parametric methodologies. $\mathrm{PhD}$ diss., Loughborough University.

32. Casu, B., B. Deng, and A. Ferrari. 2017. Post-crisis regulatory reforms and bank performance: Lessons from Asia. European Journal of Finance 23(15): 1544-1571.

33. Kumbhakar, S.C., H.-J. Wang, and A. Horncastle. 2015. Stochastic frontier analysis using STATA. Cambridge: Cambridge University Press.

34. Sealey, C.W.J., and J.T. Lindley. 1977. Inputs, outputs and a theory of production and cost at depository financial institutions. The Journal of Finance 32(4): 1251-1266.

35. Barth, J.R., G. Caprio, and R. Levine. 2004. Bank supervision and regulation: What works best? Journal of Financial Intermediation 13: 205-248.

36. Clarke, G., R. Cull, M.S. Martinez Peira, and S.M. Sanchez. 2003. Foreign bank entry: Experience, implications for developing economies and agenda for further research. The World Bank Research Observer 18(1): 25-59.

37. Belotti, F., S. Daidone, G. Ilardi, and V. Ate. 2013. Stochastic frontier analysis using Stata. STATA Journal 13(4): 719-758.

38. Zhao, T., B. Casu, and A. Ferrari. 2010. The impact of regulatory reforms on cost structure, ownership and competition in Indian banking. Journal of Banking \& Finance 34(1): 246-254.

39. Boone, J., H. van der Wiel, and J. van Ours. 2007. How (not) to measure competition. CEPR Discussion Papers 6275.

40. Boone, J. 2008. A new way to measure competition. The Economic Journal 118(531): 1245-1261.

41. Van Leuvensteijn, M., C. Kok, J.A. Bikker, and A.A. Van Rixtel. 2013. Impact of bank competition on the interest rate pass-through in the Euro area. Applied Economics 45(11): 1359-1380.

42. Schaeck, K., and M. Čihák. 2008. How does competition affect efficiency and soundness in banking? New empirical evidence. ECB Working Papers Series, WP 932, September 2008.

43. Clerides, S., M.D. Delis, and S. Kokas. 2015. A new data set on competition in national banking markets. Financial Markets, Institutions \& Instruments 24(2-3): 267-311.

44. Pellettier, A. 2018. Performance of foreign banks in developing countries: Evidence from sub-Saharan African banking markets. Journal of Banking \& Finance 88: 293-311.

45. Poshakwale, S., and B. Qian. 2011. Competitiveness and efficiency of the banking sector and economic growth in Egypt. African Development Review 23: 99-120.

Publisher's Note Springer Nature remains neutral with regard to jurisdictional claims in published maps and institutional affiliations. 
John K. Dadzie is a senior financial economist. He is currently working for the Research Department of the Bank of Ghana, having previously worked for Ecobank and Afreximbank. He has a Ph.D. in Economics from the University of Reading and is a Chartered Accountant and a Fellow of the ACCA.
Alessandra Ferrari is Associate Professor in Economics at the University of Loughborough. Having obtained a $\mathrm{PhD}$ in Economics from the University of Warwick, she is an applied microeconomist and has published extensively on performance measurement and on the efficiency and competitiveness of banks. 